\title{
Performance of Rapid Response Force in Pakistan: A Case Study of Madadgar-15 Karachi
}

\author{
Dr. Mustafa Hyder \\ Assistant Professor, Department of Public Administration, University of Karachi
}

\begin{abstract}
This study seeks to explore the issues that hinder the performance of rapid response force of Pakistan especially in Karachi. In the late 90s, the higher authority of police launched a rapid response service that has been given different names in the past, but now is known as Madadgar-15 (M-15). The research is carried out using questionnaires, office visits and interviews through random sampling and site visits using convenience sampling. Results showed that the three key agents; the government, the higher officials of Madagar-15 and the people are responsible for the performance, which should work together to achieve its real objectives and rebuild the image of Police. This study is intended to identify key indicators affecting the performance of rapid response force in Karachi. The study will highlight the police's perceptions uncovering factors that affect public support for community policing.
\end{abstract}

Keywords: Madadgar-15, Rapid Response, Performance of M-15, Policing in Pakistan

DOI: 10.7176/PPAR/9-3-18

Publication date:March $31^{\text {st }} 2019$

\section{INTRODUCTION}

Karachi is the capital of the province of Sindh, and the largest in Pakistan and among ten largest cities in the world. Located on the coast of the Arabian Sea, north-west of the Indus River Delta, the mega city is the cultural, economic, philanthropic, educational, and political hub, as well as the largest port, of the country. The metropolitan area along with its suburbs comprises the world's second most populated city, spread over 3,530 square kilometers. The city credits its growth to the mixed populations of economic and political migrants and refugees from different national, provincial, linguistic and religious origins who have largely come to settle here permanently that makes it administration a difficult task.[17-18] It is locally termed as the City of Lights for its liveliness and the City of The Quaid, for not only being both the birth and death place of Quaid-e-Azam Muhammad Ali Jinnah the founder of Pakistan but also his home after 1947. Residents and those born in the city are called "Karachiites".

The first form of government was a conservancy board established in 1846 to control the spread of cholera in the city. The board became a municipal commission in 1852 , and a municipal committee the following year. The City of Karachi Municipal Act of 1933 transformed the city administration into a municipal corporation with a mayor, a deputy mayor and 57 councilors. In 1948, the Federal Capital Territory of Pakistan was created, comprising approximately $2,103 \mathrm{~km} 2(812 \mathrm{sq} \mathrm{mi})$ of Karachi and surrounding areas, but this was merged into the province of West Pakistan in 1961. However, the municipal corporation remained in existence and in 1976 became a metropolitan corporation, followed by the creation of zonal municipal committees, which lasted until 1994 [19]. Two years later the metropolitan area was divided into five districts, each with a municipal corporation. In 2001, five districts of Karachi were merged to form the city district of Karachi. It was structured as a three-tier federation, with the two lower tiers composed of 18 towns and 178 union councils, with each tier focused on elected councils with some common members to provide "vertical linkage" within the federation. Two members are elected jointly as the union mayor (nazim) and deputy union mayor (naib nazim). Naimatullah Khan was the first Nazim of Karachi and Shafiq-Ur-Rehman Paracha was the first district coordination officer (DCO) of Karachi, Paracha even served as the last Commissioner of Karachi. Syed Mustafa Kamal was elected City Nazim of Karachi to succeed Naimatullah Khan in 2005 elections, and Nasreen Jalil was elected as the City Naib Nazim. Again in 2011, City District Government of Karachi has been de-merged into its five original constituent districts namely Karachi East, Karachi West, Karachi Central, Karachi South and District Malir. These five districts form the Karachi Division now. There are also six military cantonments which are administered by the Pakistan forces.

\section{Background Information}

The enforcement of law and preservation of peace assumes great significance in the context of developing societies for a variety of reasons. A dismally low literacy rate; mass poverty seeping into an ever-surging population; dominance of vested interest; polarization of society characterized by discriminatory sets of norms 
and rules; unrealized expectations and hopes leading to seething frustration and despair, and a host of other interrelated factors make the task of maintaining the supremacy of laws a seemingly unattainable goal.[1-3] The preservation of peace and public tranquility assumes supreme importance-not as a means of bringing about radical changes for the better but as an end in itself.

Other than formal law enforcement bodies there are many other supporting bodies with some explicit responsibilities like Rapid Respond or Action to the complains and queries[4-6]. For example '911' in America, ' 112 ' or '999' European Union, '99' to ' 108 ' in India. In Pakistan there are different such bodies one of them numbered ' 15 ' and in Karachi its name is "Madadgar-15".

The key role of the police is to ensure smooth law \& order conditions, protecting the peace through ruling and societal norms. Police is also reserved to be used as an emergency service and provide public protection at large gatherings, emergencies, calamities, and search and rescue situations[7-10] .Madadgar 15 (M-15), the Police help line, is a rapid emergency response center operating in all parts of the city, receives complaints about crimes, domestic and utilities problems and forward request to appropriate unit.

\section{UNDERSTANDING POLICE SETUP IN PAKISTAN:}

The following are ranks of Police Service of Pakistan[15-19]

1. IGP BS-22 equivalent to Lt. General

2. Additional IGP BS-21 equivalent to Major-General

3. DIG BS-20 equivalent to Brigadier

4. SSP/AIG BS-19 equivalent to Colonel

5. SP with 14 years service BS-18 equivalent to Lt.colonel

6. SP with 6 to 13 years service BS-18 equivalent to Major

7. ASP BS-17 equivalent to Captain

$>$ Additional IG, AIG and SSP are appointments

$>\mathrm{IG}, \mathrm{DIG}, \mathrm{SP}$ and ASP are ranks.

At provincial level head is IG (Inspector General of the police) who performs his duties with the assistance of a number of staff officers as follows;

a. Deputy Inspectors-General of Police

b. Deputy Inspectors-General of Police, Headquarters

c. Assistant Inspectors-General of Police

They perform multifold functions related to Establishment, Welfare, Supply of Equipment and Uniforms, Training, Finance and Welfare etc, and assist the Inspectors-General of Police.

A part from the normal duties of police, certain other ancillary or police-related functions is performed by various segments under the general supervision of the Inspector-General of Police [11-14]. The Special Branches, Provincial Crime Branches, Reserve Police, Telecommunications and Transport, Traffic and Highways Police, Police Training Colleges and Technical Cells and rapid action/response forces are headed either by a D.I.G. or a senior Superintendent of Police who gives a helping hand to the Inspector-General of Police.

Police departments in the Pakistan see Rapid Response Force as crucial to their role that they reply to calls for help rapidly [16]. The capacity of prompt actions can further be improved with the support of technology M-15 has emerged as proficient emergency system, which empowers public to have the easy and quicker access to concerned authority. The overall standing of a police department, too, can be made better if rapid response is consistent, and this in itself endorses the eradication of crime. Needless to say, rapid response offers the public some degree of contentment in its police force.

\section{FORMATION OF MADADGAR 15:}

IG Sindh Kamal Shah laid the foundation of M-15 back in 2002 as a direct relief to public on the pattern of 911 America. There is no official written documentation as to when the 15-Madadgar was set up. However through interview with DSP Abbas Rizvi, the collected information revealed that, in order to cope with the rising street crimes in the city M-15 service begun, having 15 officials equipped with 14 motorcycle riders, known as Eagles, including one LMG-fitted mobile van, two ambulances and a jeep. It is a rapid emergency response center operating in all parts of the city. Later a furnished office of Madadgar 15 Jamshaid Town started its operations on main Tariq road, which makes the total of 12 M-15 physical stations in 18 towns of Karachi. These 12 Madadgar-15 bases marking the city, functioning 24 hours a day to entertain complaints and forward evidences to appropriate police areas. 
The Basic Functions of M-15 are Missing Persons/ Child Women Complaints, Police Complaints (Non Registration of FIRs), Bomb Disposal / Fire Bridge , Ambulance Service , Electricity complaints , Sui Gas Complaints , Computer Clearance of Vehicles , Dacoits / Theft \& other Crime Complaints, Water \& Sewerage Complaints, Vehicle Snatching \& Theft Complaints, Law and Order and Legal Aid [19]

\section{M-15 COMMUNICATION CHANNEL:}

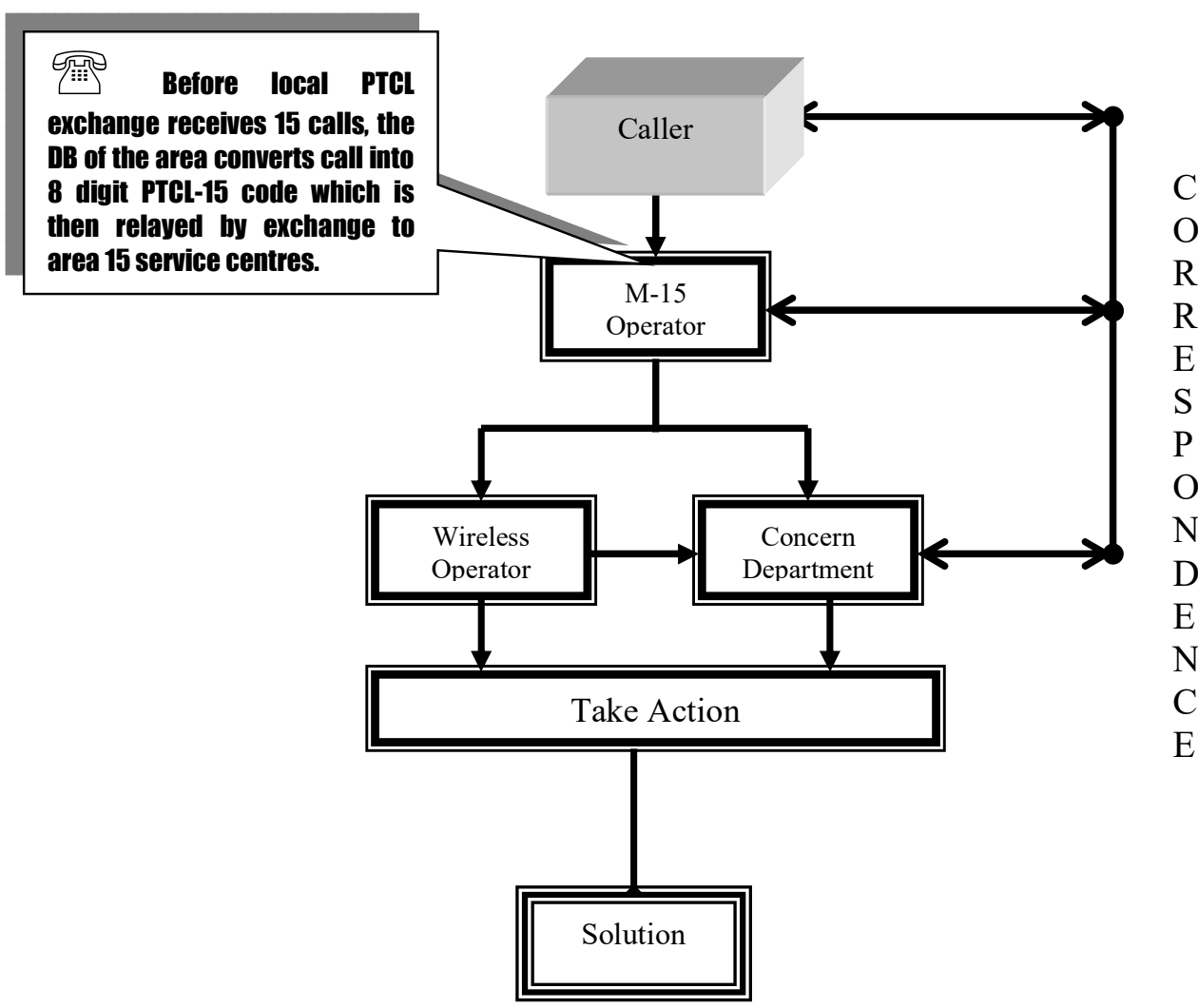

Figure 1: Shows the overall structure of M-15

\section{PERFORMANCE OF MADADGAR 15:}

The procedures and transformation of the roles, structure of police organizations and its subsidiary centers, and the performance of the people employed within them, are the broad topics of this paper. The authors direct contribution in, and observations of, extensive activities in M-15 centers form the basis of the original research, from which this paper has been developed.

\section{RESEARCH METHODOLOGIES}

For gaining the firsthand knowledge of both the M-15 and people response several visits and survey with questionnaire were made to different centers of M-15. These visits highlighted the fact that it's not only the officials who are responsible for the downfall of $\mathrm{M}-15$ but also the attitude of public that made police treats them like that. The main highlights of the visits are described below to envision the operations at M-15 offices:

- We interviewed DSP, who emphasized and brought into light the problems faced by M-15 in a prompt response to public calls. He revealed problems faced by officials and the attitude of behavior. According to him most of the times calls are irrelevant and fake asking for no help or just to entertain them in during their leisure times.

- We interviewed staff and conducted a survey through questionnaires. This survey was conducted from 20 operational staff that was present on that time. Results of this survey will be discussed in detail later in this paper. 
- We also took calls for half an hour. In these thirty minutes 50 calls were received. Most of these calls were of girls only wanting to chat and pass the time. Only one call was relevant and that was also of a minor dispute outside the shop.

- M-15 office Clifton town took us by surprise as their phone lines were dead. Only wireless set was working. We wondered what the solution to all of this was. They told in such circumstances phone calls are transferred to the nearest town. We further gathered responses through interviews with the operational staff.

\section{KEY INDICATORS AFFECTING THE PERFORMANCE OF M-15:}

Through three different questionnaires surveys taken from public, M-15 line staff and M-15 Officers following social variables or factors that determine the nature and quality of the work, efficiency, image and performance of these centers are identified, these factors are:

\section{Intra-communication}

Intra communication is essential to harmonize the efforts of the people within the force. Fast, prompt and precise communication is central in making a Madadgar-15 more proficient. This requires good and effective communication skills to be instilled within the people involved in M-15. Communication channel should be crystal clear to everyone. Lack of strong cross departmental communication hinders the productivity and efficient response. The recipients of the message should be able to infer this information appropriately and promptly.

\section{Training Programs}

It takes more than a desire to be a part of M-15. It demands much training and learning. It requires diligence, audacity and strong determination. A very central part of the rigorous training comprises of physical fitness, which requires the candidate to be in top physical condition. $70 \%$ of the response shows one of the aspects that lead to M-15 failure. The people working there are not trained. Lack of road orientation and destination maps leads to late responses. Only $30 \%$ of the officers have arranged training programs for the development of interpersonal skills. The lack of continuous physical fitness and training sessions hampers the performance negatively. Training programs with appropriate goals and objectives are fundamental to prepare for duty with physical drills, water safety, first aid, defensive and offensive training, CPR, etc.

\section{Modern Technical Facilities}

To enhance the effectiveness of performance M-15 needs to equip them with technology. Progress in technology for the M-15 has been very slow and uneven. There is no way to trace back the fake calls, no system for fielding emergency calls, obsolete and malfunctioning telecommunication equipment, no computers to automate their functions, no digital mapping, no record management system. Everything is only limited to their personal memory storing and retrieval skills.

\section{Job Satisfaction and Motivation}

The Lack of appreciation from supervisors and proper reward system lead to job dissatisfaction and demotivation. The efforts are not acknowledged. Surveys also showed the reasons contributing to their job dis satisfaction. $45 \%$ officials think inadequate income and lack of authority is responsible for their de motivation, $30 \%$ considers lack of good environment, job excitement and lack of personal growth as their de motivation factor.

\section{Sense of Ethics and Moral Values}

Corruption, ethics and integrity have become more important issues in the practice of M-15. Negating and rejecting the possibilities for ethical compromise and corruption averts administrators and officers from inculcating an in-depth understanding of the issues. This denial leads to unclear understanding, and with inadequate information and lack of practical strategies, officers who are open to a risk-filled situation endanger their professional and personal lives; as well as their repo and credibility by exhibiting inappropriate actions. The change from a committed, extremely principled officer into a self-serving individual who considers "if we don't look out for ourselves who will?" is a subtle process that frequently arises before the officers know what has happened.

\section{Public Awareness}

Although the police exist to serve the people, yet it cannot achieve this purpose without the constant support and whole-hearted co-operation of the public. But police-public relations have a difficult side also. The public, 
particularly powerful factions expect conflicting performance from the police and the police are thus often placed in a predicament. The public seldom recognizes his very human limitations. It is necessary that the public develops a better understanding of the nature of the police work, tone down its excessively critical view of police performance, and show due appreciation for the services rendered by the police. Not all the responsibility of bad performance of M-15 could be given to the force. The lack of public awareness about the functions and responsibilities of M-15 also lead to the ineffective performance which in turn creates image of dis trust. People make fake calls asking them to do their house chores or simply talk to them as they are feeling alone. However, according to the recorded response $25 \%$ people think this bad image is because of lack of friendly behavior from Madadgar- 15 side, $40 \%$ think it is because of lack of concentration on the complaint, lack of trust, justice and accountability, discrimination, lack of communication with citizens, 50\% think it's due to improper communication with different departments, $30 \%$ think its inefficiency of Police and small number of locals in force.

\section{Adequate Fund Allocation}

$90 \%$ of officers complain about the scarcity of proper resources, improper resource allocation and lack of support from Government in terms of financial funding to meet their expenses. They think Government should take a step forward to increase their budget allocation too. They are not well equipped and therefore fail to help people even if they want to. The M-15 does not have adequate means of transport and communication. This makes contact with remote area very difficult and consequently affects efficiency. Obviously the police cannot be expected to put their best foot forward so long as they are not furnished with basic, essential resources. However $10 \%$ of officers think that Government is doing on its part.

\section{RECOMMENDATIONS AND CONCLUSION:}

Performance of M-15 could be improved and maintained by giving proper working facilities to the people involved in it. This objective could be very much achieved by mobilizing these centers and agencies in an effective manner. Following necessary steps should be taken and serious consideration should be given to improve M-15 services in current situation:

1. Intra-communication of different departments should be promoted so as to increase efficiency and productivity.

2. Training Programs should be initiated so as to train and educate staff and bringing awareness in them the needs and problems of people. They should be trained to what should be done as a quick and immediate remedy. They should include first aid training as well.

3. Modern technical facilities should also be introduced in the department that can help in effective intra communication and prompt response services.

4. Job satisfaction and motivation could be increased by introducing a proper reward system which should be unbiased and fair enough to recognize the services of dedicated personnel.

5. Sense of Ethics and moral values should be invoked so as to stop from fraudulent acts.

6. Public awareness programs should be initiated so as to educate people as well of their responsibilities towards cooperation with police. They should not disrespect police and should cooperate with them.

7. Adequate fund allocation should be there on part of Government. Government should consider as its foremost duty to serve public and therefore should allocate such a budget that can meet M-15 expenses and at the same time give its workforce an opportunity to increase their life standards too.

8. Proper road orientation should be taught to M-15 drivers and also the proper and sufficient vehicles.

9. Attitude of supervisors should be improved while treating their subordinates. Mutual understanding should be there and proper feedback should be taken from lower staff too so as so to increase creativity and new ideas to serve people better.

10. Efficiency Reports should be published so that officials and staff also feel accountable for their practices. This will also increase awareness in public and will be an opportunity to rebuild the lost trust. How much M-15 has achieved can also be analyzed through these reports.

11. The basic idea to develop an autonomous M-15 Service is to provide unbiased, efficient and rapid service to public, since M-15 not taking any grant from government it won't be the burden on government.

12. The whole system will be thoroughly checked and monitored by public representatives and media.

13. There should be involvement of media electronic and print, in monitoring performance as well as efficiency of M-15 and also to improve image and develop confidence of public on M-15.

14. Madadgar should be made fully automated and online so as to spread its services to distant corners as well.

15. The introduction of the "e-M15" emergency system will facilitate public with the easier and prompt connection with police. The use of computer systems and data communication will also assist police in 
scheduling patrols and guards, and allocating emergency requirements to the police officers at the spot of the crime.

16. The command and control system through CCTV cameras and satellite navigation system should be more operational.

\section{References}

Bayley, David H. and Egon Bittner. 1984. "Learning the Skills of Policing." Law and Contemporary Problems 47:35-59.

Bittner, Egon. 1970. The Functions of the Police in Modern Society: A Review of the Background Factors, Current Practices, and Possible Role Models. Chevy Chase, MD: National Institute of Mental Health.

Bittner, Egon. 1983. "Legality and Workmanship." In Maurice Punch, ed., Control in the Police Organization. Cambridge, MA: MIT Press.

Cordner, Gary \& Elizabeth Perkins Biebel. 2005. "Problem-oriented Policing in Practice." 4 Criminology and Public Policy 155-180.

Crank, John P. and Robert Langworthy. 1992. "An Institutional Perspective of Policing." The Journal of Criminal Law and Criminology 38:338-363.

Ericson, Richard V. and Kevin D. Haggerty. 1997. Policing the Risk Society. Toronto: University of Toronto Press.

Finkelstein, S. and D. C. Hambrick. 1996. Strategic Leadership: Top Executives and Their Effects on Organizations. Minneapolis/St. Paul, MN: West.

Engel, Robin S. 2000. "Effects of Supervisory Styles on Patrol Officer Behavior.” Police Quarterly 3:262-293.

Fogelson, Robert M. 1977. Big City Policing. Cambridge, MA: Harvard University Press.

Goldstein, H.. 1990. Problem-oriented Policing. New York: McGraw-Hill.

Gould, Jon B. and Stephen D. Mastrofski. 2004. "Suspect Searches: Assessing Police

Behavior under the Constitution." Criminology and Public Policy 3: 316-362.

Greenspan, Rosann. (2003) Compstat and Organizational Change: Short Site Visit Report. Washington, DC: Police Foundation.

Guyot, Dorothy. 1979. "Bending Granite: Attempts to Change the Rank Structure of American Police Departments." Journal of Police Science and Administration 7:253-284.

Heffernan, William C. And Richard W. Lovely. 1990/1991. "Evaluating the Fourth Amendment Exclusionary Rule: The Problem of Police Compliance with the Law." University of Michigan Journal of Law Reform 24:311369.

http://www.sindhpolice.gov.pk/

http://www.scribd.com/doc/24031499/Pakistan-Police

http://www.kmc.gos.pk/

http://www.cssforum.com.pk/css-cadres-training-programmes/specialized-training-program-stp/police-servicepakistan/4490-police-service-pakistan-psp-ranks.html 